\title{
Atropine-induced non-sustained polymorphic ventricular tachycardia: A rare case
}

\section{Nadir bir olgu: Atropinin indüklediği sürekli olmayan polimorfik ventriküler taşikardi}

Mesut Aydın, Abdulkadir Yıldız, Nihat Polat, Halit Acet, Yahya İslamoğlu

\begin{abstract}
A 40 years old male with history of unexplained recurrent presyncope and palpitation episodes referred to cardiology department. Patient had no past medical history. Subsequently, electrophysiology study was performed to detect any underlying atrioventricular nodal disease or inducible tachyarrhythmias. During this period, 1.0 $\mathrm{mg}$ of atropine was injected intravenously to performed stimulation and patient suddenly developed polymorphic ventricular tachycardia that could not be terminated with overdrive pacing. Ventricular tachycardia was terminated spontaneously, two minutes later. J Clin Exp Invest 2014; 5 (3): 449-451
\end{abstract}

Key words: ventricular tachycardia, atropine, presyncope

\section{INTRODUCTION}

Cardiac functions are under the influence of autonomic nervous system. There is sufficient evidence that proves an imbalance in this autonomic regulation predisposes to electrical instability and ventricular tachyarrhythmias [1]. Atropine is commonly used in the treatment of bradyarrhythmias and in electrophysiologic studies. After atropine usage changes of autonomic balances on heart may result in ventricular tachyarrhythmias. Here, we report a case of polymorphic ventricular tachycardia (VT) induced by atropine with hemodynamic deterioration and subsequent recovery to normal hemodynamic status.

\section{CASE REPORT}

A 40 years old male with history of unexplained recurrent presyncope and palpitation episodes re-

\section{ÖZET}

Tekrarlayan çarpıntı ve presenkop şikayetleri ile 40 yaşında erkek hasta kardiyoloji kliniğine başvurdu. Hastanın öz geçmişinde herhangi bir özellik yoktu. Atriyoventriküler nod hastalığı veya taşiaritmi indüklemek için elektrofizyolojik çalışma yapıldı. Atropin $1.0 \mathrm{mg}$ yapıldıktan sonra testin tekrarlanması planlandı. Bu esnada polimorfik ventriküler taşikardi gelişti. Overdrive pacing ile taşikardi sonlanmadı yaklaşık 2 dakika sonra spontan olarak sonlandı.

Anahtar kelimeler: ventriküler taşikardi, atropin, presenkop

ferred to cardiology department. Presyncope was preceded by palpitations, shortness of breath, and atypical chest pain. Patient had no past medical history. On admission, vital signs were stable with an unremarkable physical examination. Electrocardiogram showed normal sinus rhythm at 74 beats per minute with normal intervals (Figure 1). All cardiac work up for presyncope including echocardiogram, 24-hour Holter monitoring, and tilt table test were in normal limits. Subsequently, electrophysiology study was performed to detect any underlying atrioventricular (AV) nodal disease or inducible tachyarrhythmias. Neither atrial nor VT could be induced by programmed atrial and ventricular stimulation. Wenckebach point of AV node was $310 \mathrm{~ms}$. During this period, $1.0 \mathrm{mg}$ of atropine was injected intravenously to repeated stimulation and patient developed polymorphic VT that could not be terminated with overdrive pacing (Figure 2, and 3). Subsequently, the patient became hypotensive, felt 
lightheadness and dizziness; however, consciousness was not lost. We administered amiodarone $300 \mathrm{mg}$ intravenously. Ventricular tachycardia was terminated, two minutes later (Figure 4). Bedside echocardiogram yielded normal cardiac structures without any pericardial effusion. At the same session, coronary angiogram was performed revealing normal coronary arteries. Later, cardiac magnetic resonance imaging ruled out any cardiomyopathy.
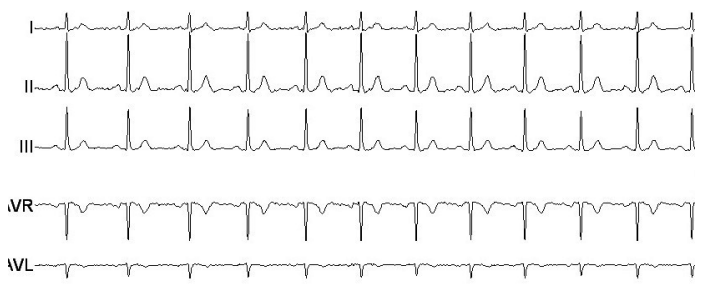

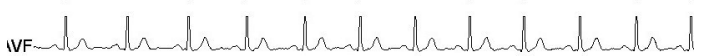

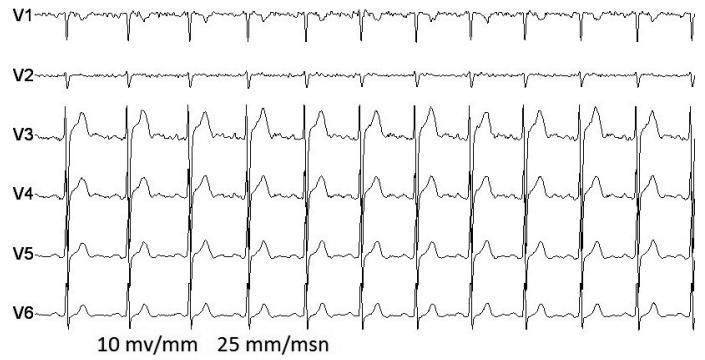

Figure 1. Electrocardiography with sinus rhythm

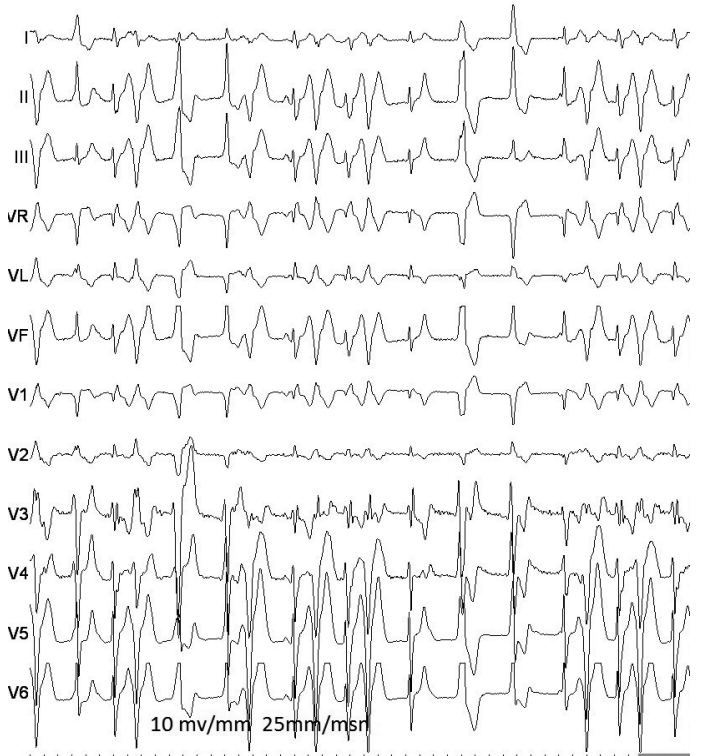

Figure 2. Electrocardiography with polymorphic ventricular tachycardia

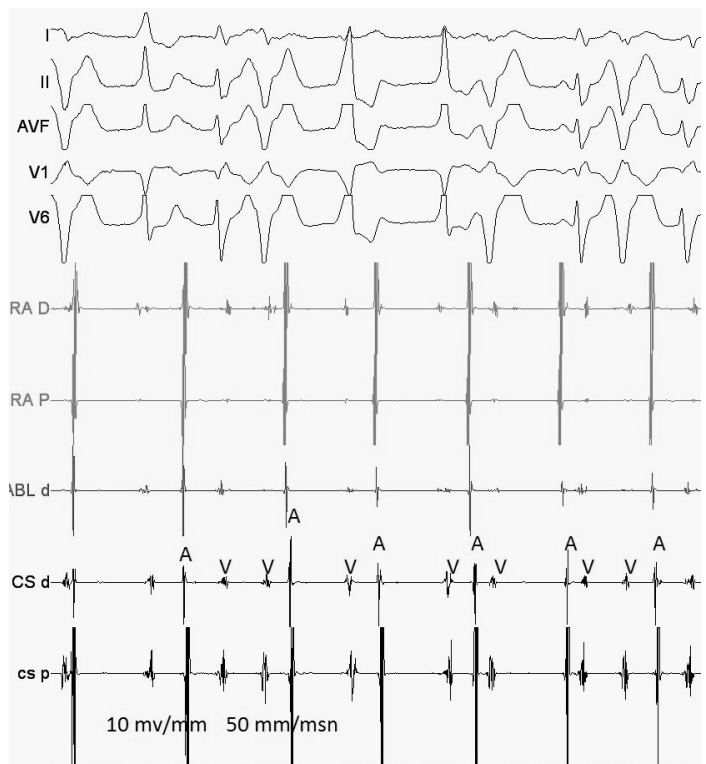

Figure 3. Simultaneous recordings of surface leads together with high right atrium, coronary sinus and ablation catheter electrogram with polymorphic ventricular tachycardia. A: atrial depolarization, V: ventricular depolarization

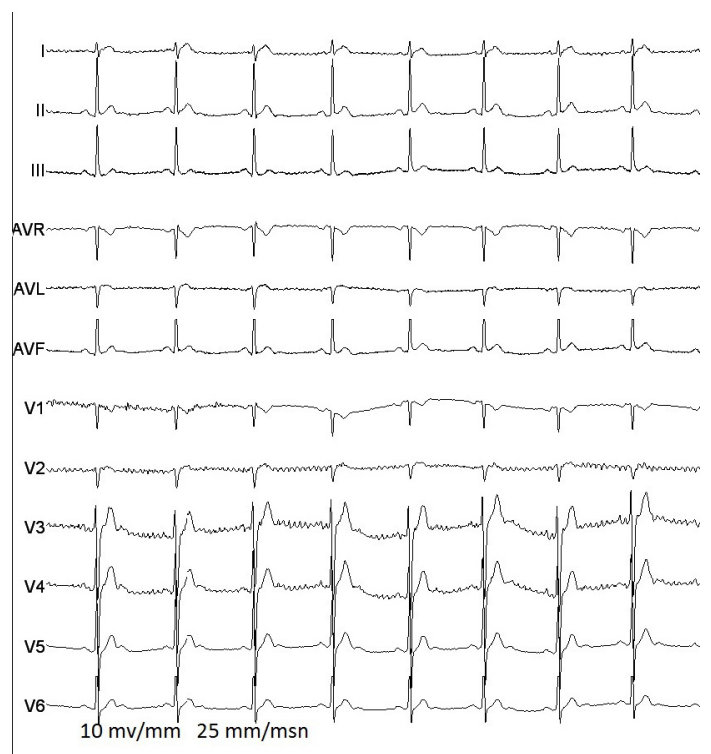

Figure 4. Electrocardiography with sinus rhythm

\section{DISCUSSION}

Most of the cardiac sudden deaths are due to malignant ventricular arrythmias [2]. The appearance of ventricular tachyarrhythmias including VT and ventricular fibrillation following atropine therapy during the course of heart rate acceleration has been described in the presence of significant ischemic 
heart disease $[2,3]$. There is clinical evidence that reduced vagal activity is associated with increased risk for life-threatening arrythmias after myocardial infarction, and increased vagal tone may protective effect against ventricular arrythmias [5]. It has been reported that vagal nerve stimulation exerts an antiarrhythmic effect in rat model of myocardial infarction [6]. In a study, a dose of 0.8-1.2 mg intravenous atropine was demonstrated to induce arrhythmias in patients with or without heart disease [7].

An enhanced sympathetic drive of the heart and catecholamines play a major role in the pathophysiology of ventricular arrhythmias, whereas an augmented vagal tone and strong vagal stimuli depress sinus node activity and AV nodal propagation [8]. Fei et al. showed idiopathic VT episodes was attributed to a decrease in parasympathetic activity rather than an enhanced sympathetic activity [1]. Atropine-induced VT can be explained by both the initial decrease in parasympathetic activity and an unopposed sympathetic activity.

The exact mechanism responsible for the production of ventricular irritability after atropine administration is not entirely clear. Atropine induced tachycardia leading to an increase in myocardial oxygen demand appears to be one possible explanation especially in an ischemic myocardium. The fibrillation threshold is lowered and the disparity of refractory periods becomes greater at faster rates when the myocardium is ischemic. This increase in disparity will lead to slow, nonhomogenous spread of impulses, resulting in reentrant activity and eventually ventricular fibrillation. Moreover the efflux of potassium from the myocardial cells associated with tachycardia may have an important role in promoting ventricular irritability by bringing the resting potential down towards the threshold potential. Increased extracellular potassium may also depress conduction and induce reentry $[3,9]$. The increased heart rate may cause ventricular extrasystoles even in the absence of coronary artery disease [10].

Past dog studies in which the His bundle has been exposed by careful dissection suggest that vagal stimulation or acetylcholine may have an effect on specialized conduction fibers at and below the bundle of His. Atropine by removing the parasympathetic system's inhibitory effect on the electrical pathways might possibly cause unopposed sympathetic activity [9]. This unopposed sympathetic activity may result in ventricular tachyarrhythmias. Considering the above mechanisms beta blockers can be used in patients with sensitive sympathetic drive to prevent $\mathrm{VTs}$.
In conclusion, spontaneously developed polymorphic VT probably developed due to the unopposed effect of sympathetic nervous system on heart which was caused by atropine injection. It is essential to emphasize that increased sympathetic drive to the heart is arrhythmogenic, whereas vagal activity may exert a protective effect. The apparent provocation of arrhythmias by atropine observed in the present report may be an infrequent entity and its judicious use should be accompanied by close monitoring and intravenous B-blocker use if necessary. Patients may have favorable outcomes with beta blockers.

\section{REFERENCES}

1. Fei L, Statters DJ, Hnatkova K, et al. Change of autonomic influence on the heart immediately before the onset of spontaneous idiopathic ventricular tachycardia. J Am Coll Cardiol 1994;24:1515-1522.

2. Wu W, Lu Z. Loss anti-arrhytmic effect of vagal nerve stimulation on ischemia-induced ventricular tachyarrhytmia in aged rats. Tohoku J Exp Med 2011:223;2733.

3. Massumi RA, Mason DT, Amsterdam EA, et al. Ventricular fibrillation and tachycardia after intravenous atropine for treatment of bradycardias. N Engl J Med 1972;287:336-338

4. Goel VK, Mehrotra TN, Gupta SK. Ventricular tachyarrhythmias: complication of atropine therapy in acute myocardial infarction. Indian Heart J 1981;33:301302.

5. La Rovere MT, Bigger JT Jr, Marcus FI, et al. Baroreflex sensitivity and heart-rate variability in prediction of total cardiac mortality after myocardial infarction. ATRAMI (Autonomic Tone and Reflaxes After Myocardial Infarction) Investigators. Lancet 1998;351:478-484.

6. Ando M, Katare RG, Kakinuma Y, et al. Efferent vagal nerve stimulation protects heart against ischemia-induced arrhytmias by preserving connextin43 protein. Circulation 2005:112;164-170.

7. Averill KH, Lamb LE. Less commonly recognized actions of atropine on cardiac rhythm. Am J Med Sci 1959;237:304-318.

8. Coumel P, Rosengarten MD, Leclercq JF, Attuel P. Role of sympathetic nervous system in non-ischaemic ventricular arrhythmias. Br Heart J 1982;47:137-147.

9. Zipes DP, Knoebel SB. Rapid rate-dependent ventricular ectopy: adverse response to atropine induced rate increase. Chest 1972;62:255-258.

10. Berkowitz WD, Young MW, Scherlage BJ, et al. Rate dependency of cardiac glycoside action on atrioventricular (AV) conduction and ventricular automaticity. Clin Res 1968;16:222. 